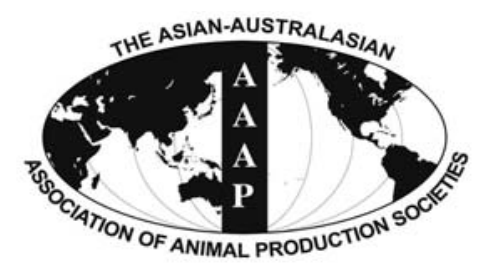

Asian-Aust. J. Anim. Sci.

Vol. 22, No. 9 : 1296 - 1302

September 2009

\title{
The Effect of Clinoptilolite in Low Calcium Diets on Performance and Eggshell Quality Parameters of Aged Hens
}

\author{
Şerife Şule Gezen*, Mustafa Eren, Faruk Balcı ${ }^{1}$, Gülay Deniz, Hakan Biricik and Birgül Bozan \\ Uludag University, Faculty of Veterinary Medicine, Department of Animal Nutrition and Nutritional Diseases \\ 16059, Bursa, Turkey
}

\begin{abstract}
Ninety six beak-trimmed 72 week-old Lohmann Brown hens were randomly divided into four equal groups. Each group comprised 4 replicates. Isoenergetic and isonitrogenous experimental diets contained low calcium (3.5\%); optimum calcium (4.2\%); low Ca $(3.5 \% \mathrm{Ca})+1 \%$ Clinoptilolite (CLP); low Ca $(3.5 \% \mathrm{Ca})+2 \%$ CLP. Data were collected biweekly and the experiment lasted 6 weeks. Egg production, feed consumption, feed conversion ratio, egg weight, tibia $\mathrm{Ca}$, P, ash and eggshell thickness were not affected by addition of CLP to the diets $(p>0.05)$. There were no significant differences in egg shell strength and ash when data were analyzed individually in measurement periods $\left(74^{\text {th }}, 76^{\text {th }}\right.$ and $78^{\text {th }}$ weeks). However, according to pooled data $\left(74^{\text {th }}-78^{\text {th }}\right.$ weeks), eggshell strength was increased $(\mathrm{p}<0.05)$ only by $2 \%$ CLP supplementation versus low Ca $(3.5 \%)$ diet, and shell ash was significantly increased by $2 \%$ CLP supplementation compared with the other diets. The damaged egg ratio on $1 \%$ and $2 \%$ CLP diets was significantly decreased between 76-78 weeks' data when compared with the low Ca diet. However; damaged egg ratio on the $2 \%$ CLP diet was significantly decreased when pooled data (74-78) were compared with no CLP diets. The differences in marketable egg ratio paralleled damaged egg ratio. The plasma calcium level at the end of experiment was increased on the $2 \%$ CLP diet when compared with the low Ca (3.5\%) diet $(p<0.05)$. Furthermore, at the end of the experiment a marked decrease of manure moisture was observed on both CLP diets $(p<0.01)$. In conclusion, Clinoptilolite (2\%) supplementation to layer diets tends to improve eggshell quality and manure dry matter (1\% and $2 \%$ CLP) after six weeks. (Key Words : Aluminosilicate, Clinoptilolite, Laying Hen, Eggshell Quality, Manure Dry Matter, Tibia)
\end{abstract}

\section{INTRODUCTION}

Clinoptilolite (CLP) is one of the natural zeolites. Zeolites are crystalline, hydrated aluminosilicates of alkali (e.g. $\mathrm{Na}^{2+}, \mathrm{K}^{+}$) and alkaline (e.g. $\mathrm{Mg}^{2+}, \mathrm{Ca}^{2+}$ ) earth cations, having infinite 3-dimensional structures (Mumpton and Fishman, 1977). There are nearly 50 different types of natural zeolites (CLP, mordenite, etc.) with varying physical and chemical properties (Anonymous, 2007). Zeolites have the ability to lose and gain water reversibly and to exchange constituent ionic cations (Street, 1994). Zeolites are formed from tetrahedral of silica $\left(\mathrm{SiO}_{4}\right)^{4-}$ and aluminium $\left(\mathrm{AlO}_{4}\right)^{5-}$. Each $\mathrm{AlO}_{2}$ location in the framework of zeolite requires a cation (e.g. $\mathrm{Ca}^{2+}$ ) to neutralize the compound. Also, it has been suggested that zeolites may selectively retain and release $\mathrm{Ca}$ as it passes through the digestive system (Roland

\footnotetext{
* Corresponding Author: Şerife Şule Gezen. Tel: +90-2242941202, Fax: +90-224-2941365, E-mail: gezens@uludag.edu.tr

${ }^{1}$ Uludag University, Faculty of Veterinary Medicine, Department of Zootechnics, 16059, Bursa, Turkey.

Received December 3, 2008; Accepted April 13, 2009
}

et al., 1985).

Egg breakage due to poor eggshell quality related to weak shell strength and the occurrence of bone fragility in aged hens are major problems in the poultry industry (Patterson et al., 2001). Laying hens require greater intake of Ca for egg shell formation (Roland, 1980). Thereby, increasing calcium absorption might lead to improve eggshell quality and decrease at occurrence of bone fracture.

It has been hypothesized that the beneficial effect of zeolite on shell quality may be associated with its high affinity to calcium and its high ion-exchange capacity (Roland, 1988; Roland and Dorr, 1989). These high and reversibly ion-exchange capacity $(7,0 \mathrm{meq} / \mathrm{g})$ of zeolite may enhance the utilization of calcium. Beneficial effects may also be related to the $\mathrm{Al}, \mathrm{Si}$, or $\mathrm{Na}$ content of zeolite because these minerals influence $\mathrm{Ca}$ metabolism (Carlisle, 1981). Also, Ballard and Edwards (1988) reported that male broiler chicks fed diets containing $1 \%$ synthetic sodium zeolite (SZ) increased absorption of orally and intramuscularly administered ${ }^{47} \mathrm{Ca}$.

It has been reported that feeding laying hens with CLP 
improves eggshell quality (Roland et al., 1985; Olver, 1989; Keshavarz and McCormick, 1991), the exact mechanism which responsible for this improvement on eggshell quality is not clearly known. Roland et al. (1985) hypothesized that the beneficial effect of CLP on eggshell quality is related to its high affinity for $\mathrm{Ca}$ and its high ion-exchange capability. Also, dietary SZ was significantly improved eggshell quality of the young birds fed with suboptimal dietary calcium levels (Roland and Dorr, 1989). On the other hand, SZ supplementation to feed was reported to improve growth rate, tibia bone ash and reduce the incidence and severity of tibial dyschondroplasia in broilers fed low calcium diets (Ballard and Edwards, 1988; Leach and Burdette, 1990). In contrast a decrease growth rate and tibia bone ash in adequate calcium diets (Leach and Burdette, 1990).

The other factor about zeolites on egg shell quality may be silicon. Recent studies suggest that dietary silicon may play an important role in the growth and development of bone, cartilage and connective tissues (Seaborn and Nielsen, $2002 a, b)$. The primary effect of silicon in bone and cartilage is thought to be on matrix synthesis (with formation of the organic matrix appearing to be more severely affected by silicon deficiency than the mineralization process) (Seaborn and Nielsen, 1994a, b). Also, a relationship between silicon, magnesium and fluorine on bone formation of chicks has been reported (Carlisle, 1981). Besides, dietary silicon increased the percentage of bone ash and calcium content in the tibia of rats when they were fed a low $\mathrm{Ca}$ diet rather than a high $\mathrm{Ca}$ diet (Carlisle, 1986).

There is information about effect of zeolites on eggshell quality in young hens and role of $\mathrm{Ca}$ and silicon on some tissues. In this study, it is aimed to test the effect of CLP which is a natural zeolite on the performance, eggshell quality parameters, blood calcium, manure dry mater and tibia characteristics of aged hens fed diets containing low levels of calcium.

\section{MATERIAL AND METHODS}

\section{Experimental material}

A total of 96 beak-trimmed Lohmann Brown 72 weeks old hens were used. They were reared in cages $(60 \times 45 \times 40$ $\mathrm{cm}^{3}$ ) under conventional conditions with access to feed and water (municipality tap water) ad libitum and with constant daily $16 \mathrm{~h}$ lighting. All diets were in the meal form based on corn and soybean meal. The diets were formulated to be isonitrogenous $(162.1 \mathrm{~g} / \mathrm{kg})$ and isocaloric $(2,600 \mathrm{kcal} / \mathrm{kg})$ as fed basis (Table 1).

The mineralogical composition of the natural zeolite used in this experiment is 88\% CLP, 5\% Smektit, 5\% OpalCT, 2\% Quartz. CLP was mined from Gördes-ManisaTURKEY and the chemical formula of pure CLP is
$\left(\mathrm{Na}_{0.5} \mathrm{~K}_{2.5}\right) \quad\left(\mathrm{Ca}_{1.0} \mathrm{Mg}_{0.5}\right) \quad\left(\mathrm{Al}_{6} \mathrm{Si}_{30}\right) \quad \mathrm{O}_{72} 24 \mathrm{H}_{2} \mathrm{O} . \quad$ The composition of CLP used in the experiment is shown in Table 2 .

\section{Treatments and experimental protocol}

Hens with similar egg production capabilities and live weight were divided into four equal main groups. Each of the main groups comprises 4 replicates at 4 cages. Hens were randomly distributed into 16 cages, 6 hens per cage. A practical layer diet was provided during the experiment. Experimental diet groups were design as follows:

Low Ca group: 3.5\% calcium, no CLP

Opt. Ca group: $4.2 \%$ calcium, no CLP

$1 \%$ CLP group: $3.5 \%$ calcium $+1 \%$ CLP

$2 \%$ CLP group: $3.5 \%$ calcium $+2 \%$ CLP

The experiment was carried out between the February $11^{\text {th }}$ and March $26^{\text {th }}$ (6 weeks). During this time, the daily average temperature was $16^{\circ} \mathrm{C}$. Relative air humidity was $65 \%$ through the experiment.

\section{Chemical analysis and measurement of eggshell quality}

Experimental diets were chemically analyzed according to the AOAC methods (1984). Metabolisable energy of the experimental diets was calculated using the equation of Hartel (1977) as follows:

$$
\begin{aligned}
\operatorname{ME}(\mathrm{kcal} / \mathrm{kg})= & 239 \times((\text { Ether extract, } \% \times 0.3431) \\
& +(\text { Crude protein, } \% \times 0.1551) \\
& +(\text { Saccharose }, \% \times 0.1301) \\
& +(\text { Starch, } \% \times 0.1669)) .
\end{aligned}
$$

Hen day egg production and damaged eggs were recorded daily. The feeds were weighed every 14 days to determine feed consumption and FCR. Eggs were collected at the beginning and continued biweekly during the trial. Two eggs collected from each replication and determination of egg quality parameters (egg weight, eggshell quality) were done after one day of collection. All eggs were visually checked for cracks and breakage under artificial lighting. The exterior shell quality evaluations were based on shell thickness, breaking strength and shell ash. The eggshell breaking strength was measured using a cantilever system by applying increased pressure to the broad pole of the shell (Balnave and Muheereza, 1997). The shell thickness was measured with a micrometer gauge (mitutoya $^{\circledR}$ ) on three part of shell from the equator of each egg. The shell ash was determined after drying at room temperature for 3 days.

Blood samples were drawn from the brachial vein into heparinised syringes. Thereafter, blood samples were centrifuged for $15 \mathrm{~min}$ at $1,500 \times \mathrm{g}$ and plasmas were stored 
Table 1. Composition and nutritive value of experimental diet (as fed basis)

\begin{tabular}{|c|c|c|c|c|}
\hline Ingredients (\%) & Low $\mathrm{Ca}(3.5 \%)$ & Optimum $\mathrm{Ca}(4.2 \%)$ & $1 \%$ CLP & $2 \%$ CLP \\
\hline Corn & 51.46 & 51.46 & 51.46 & 51.46 \\
\hline Barley & 5.00 & 5.00 & 5.00 & 5.00 \\
\hline Soybean meal (440 g CP/kg) & 11.00 & 11.00 & 11.00 & 11.00 \\
\hline Full fat soybean & 9.90 & 9.90 & 9.90 & 9.90 \\
\hline Sunflower meal (320 g CP/kg) & 9.00 & 9.00 & 9.00 & 9.00 \\
\hline Vegetable oil & 1.00 & 1.00 & 1.00 & 1.00 \\
\hline Dicalcium phosphate & 1.27 & 1.27 & 1.27 & 1.27 \\
\hline Limestone (ground) & 8.51 & 10.45 & 8.51 & 8.51 \\
\hline Carofil & 0.10 & 0.10 & 0.10 & 0.10 \\
\hline Vitamin premix* & 0.25 & 0.25 & 0.25 & 0.25 \\
\hline Mineral premix $* *$ & 0.10 & 0.10 & 0.10 & 0.10 \\
\hline $\mathrm{BHT}^{* * *}$ & 0.01 & 0.01 & 0.01 & 0.01 \\
\hline DL-methionine & 0.05 & 0.05 & 0.05 & 0.05 \\
\hline Salt & 0.35 & 0.35 & 0.35 & 0.35 \\
\hline Sand & 2.00 & 0.06 & 1.00 & - \\
\hline CLP & - & - & 1.00 & 2.00 \\
\hline Total & 100 & 100 & 100 & 100 \\
\hline \multicolumn{5}{|l|}{ Composition (Analysed) } \\
\hline Dry matter (\%) & 89.84 & 89.63 & 89.47 & 89.42 \\
\hline Crude protein $(\%)$ & 16.22 & 16.30 & 16.21 & 16.21 \\
\hline Crude fat $(\%)$ & 4.50 & 4.50 & 4.52 & 4.52 \\
\hline Crude ash (\%) & 14.43 & 14.44 & 14.46 & 14.46 \\
\hline Starch (\%) & 38.04 & 38.04 & 38.07 & 38.24 \\
\hline Sugar (\%) & 3.89 & 3.89 & 3.65 & 3.89 \\
\hline Lysine $(\%)^{* * * *}$ & 0.87 & 0.87 & 0.87 & 0.87 \\
\hline Methionine $(\%)^{* * * *}$ & 0.42 & 0.42 & 0.42 & 0.42 \\
\hline Calcium (\%) & 3.54 & 4.21 & 3.49 & 3.51 \\
\hline Total phosphorus (\%) & 0.56 & 0.54 & 0.54 & 0.55 \\
\hline Metabolisable energy $(\mathrm{kcal} / \mathrm{kg})^{* * * *}$ & 2,604 & 2,618 & 2,609 & 2,612 \\
\hline
\end{tabular}

* Vitamin premix supplied the following per kg diet: Retinol 10,000 IU, cholecalciferol 2,000 IU, tocopherol $15 \mathrm{mg}$, vitamin $\mathrm{K}_{3} 2 \mathrm{mg}$, thiamin $1 \mathrm{mg}$, riboflavin $6 \mathrm{mg}$, pyridoxine $2 \mathrm{mg}$, cyanocobalamin $0.015 \mathrm{mg}$, folic acid $1 \mathrm{mg}$, calcium d- pantothenate $8 \mathrm{mg}$, $\mathrm{d}$ - biotin $0.05 \mathrm{mg}$, niacin $33 \mathrm{mg}$.

** Trace mineral premix supplied the following per $\mathrm{kg}$ diet: Manganese $100 \mathrm{mg}$, iron $25 \mathrm{mg}$, zinc $6 \mathrm{mg}$, copper $5 \mathrm{mg}$, iodine $0.5 \mathrm{mg}$, cobalt $0.1 \mathrm{mg}$, selenium $0.2 \mathrm{mg}$.

*** BHT $=$ Butylated hydroxytoluene, as antioxidant.

$* * * *$ Calculated.

at $-20^{\circ} \mathrm{C}$ prior to analyses of $\mathrm{Ca}$. Plasmas were analyzed by a spectrophotometer (Novaspec ${ }^{\circledR}$ II, Mod 4040) with using commercial kit (Teco diagnostics). At the end of trial, eight hens from each group were killed and the left tibias were stored until determination of bone ash (AOAC, 1955). For bone ash analysis, the bones were placed in boiling water to loosen only the flesh, after boiling bones were chilled and stripped of adhering flesh with care to leave the cartilage caps on the bones. Bones were extracted for $24 \mathrm{~h}$ with each ethanol and anhydrous ether and than dried, weighed, determined ash content $\left(24 \mathrm{~h}\right.$, at $\left.600^{\circ} \mathrm{C}\right)$ and re-weighed. Furthermore, bone $\mathrm{Ca}$ (glioxal-bis) and $\mathrm{P}$ (ammonium molybdate) level were examined in tibia bones (photometrically). The manure moisture was determined $\left(105^{\circ} \mathrm{C}, 6 \mathrm{~h}\right)$ at the beginning and end of the experiment by taking random specimens from each pen.

\section{Statistical analysis}

The data were analysed with analysis of variance as individually for each measurement period and pooled entire (except first day data) experimental data. Differences between means of treatments were tested according to Tukey's test (1949). All analyses were performed using SPSS $^{\circledR} 10.00$ (SPSS Inc., Chicago, USA, 1999) computer software. Differences were considered significant when $p$ values were less than 0.05 . 
Table 2. Chemical composition of CLP used in the experiment $(\%)^{*}$

\begin{tabular}{lc}
\hline Chemical composition & \\
\hline $\mathrm{SiO}_{2}$ & 66.82 \\
$\mathrm{Al}_{2} \mathrm{O}_{3}$ & 11.71 \\
$\mathrm{Fe}_{2} \mathrm{O}_{3}$ & 1.78 \\
$\mathrm{MgO}$ & 0.97 \\
$\mathrm{CaO}$ & 2.43 \\
$\mathrm{Na}_{2} \mathrm{O}$ & 0.78 \\
$\mathrm{~K}_{2} \mathrm{O}$ & 3.35 \\
$\mathrm{TiO}_{2}$ & 0.09 \\
$\mathrm{P}_{2} \mathrm{O}_{5}$ & $<0.01$ \\
$\mathrm{MnO}$ & 0.04 \\
$\mathrm{Cr}_{2} \mathrm{O}_{3}$ & $<0.001$ \\
Lost of ignition (LOL) & 12.1 \\
& (5\% Smektit, 5\% Opal-CT, 2\% Quartz) \\
\hline
\end{tabular}

* Analysed at ACME Analytical Lab (Vancouver, Canada).

\section{RESULTS}

For the total experimental period ( 72 to 78 week), feed consumption, feed conversion ratio (FCR) and egg production were not statistically different between groups (Table 3). There were no significant differences in egg weight and shell thickness by CLP supplementation (Tables 3 and 4). Also there were no significant differences in egg shell strength and ash when data of these parameters analyzed individually in measurement periods $\left(74^{\text {th }}, 76^{\text {th }}\right.$ and $78^{\text {th }}$ weeks) but there were significant differences when data of 74-78 weeks were pooled. According to pooled data, eggshell strength (Table 4$)$ was increased $(\mathrm{p}<0.05)$ only by $2 \%$ CLP supplementation versus low Ca (3.5\%) group and shell ash were significantly increased in $2 \%$ CLP supplementation more than the other groups. The damaged egg ratio of $1 \%$ and $2 \%$ CLP group was significantly decreased 76-78 weeks data when compared with low $\mathrm{Ca}$ (Table 4). However; damaged egg ratio of $2 \%$ CLP group

Table 3. The effect of CLP on performance (feed consumption, FCR, egg production, egg weight)

\begin{tabular}{|c|c|c|c|c|c|c|}
\hline \multirow{2}{*}{ Parameters } & \multicolumn{6}{|c|}{ Groups } \\
\hline & $\mathrm{N}$ & Low $\mathrm{Ca}(3.5 \%)$ & Optimum $\mathrm{Ca}(4.2 \%)$ & $1 \%$ CLP & $2 \%$ CLP & $\mathrm{P}$ \\
\hline \multicolumn{7}{|l|}{ Feed consumption (g/hen per $\mathrm{d})$} \\
\hline $72-74$ week & 4 & $112.1 \pm 3.63$ & $111.4 \pm 1.08$ & $111.3 \pm 3.31$ & $107.9 \pm 3.29$ & NS \\
\hline 74-76 week & 4 & $128.1 \pm 3.11$ & $119.4 \pm 6.75$ & $127.6 \pm 1.85$ & $129.7 \pm 1.53$ & NS \\
\hline 76-78 week & 4 & $125.4 \pm 3.07$ & $127.8 \pm 4.47$ & $125.7 \pm 4.77$ & $127.6 \pm 3.57$ & NS \\
\hline Total (74-78) & 12 & $121.8 \pm 2.72$ & $119.6 \pm 3.18$ & $121.5 \pm 2.85$ & $121.7 \pm 3.34$ & NS \\
\hline \multicolumn{7}{|l|}{ FCR ( $\mathrm{kg}$ of feed/kg of egg) } \\
\hline 72-74 week & 4 & $2.13 \pm 0.07$ & $2.21 \pm 0.12$ & $2.05 \pm 0.11$ & $2.50 \pm 0.13$ & NS \\
\hline 74-76 week & 4 & $2.28 \pm 0.03$ & $2.35 \pm 0.18$ & $2.42 \pm 0.18$ & $2.35 \pm 0.15$ & NS \\
\hline 76-78 week & 4 & $2.41 \pm 0.15$ & $2.58 \pm 0.19$ & $2.30 \pm 0.13$ & $2.65 \pm 0.18$ & NS \\
\hline Total (74-78) & 12 & $2.27 \pm 0.06$ & $2.38 \pm 0.10$ & $2.26 \pm 0.09$ & $2.50 \pm 0.09$ & NS \\
\hline \multicolumn{7}{|l|}{ Egg production (\% eggs/hen per $\mathrm{d})$} \\
\hline 72-74 week & 4 & $72.9 \pm 3.46$ & $72.2 \pm 0.80$ & $73.7 \pm 1.45$ & $72.7 \pm 0.97$ & NS \\
\hline 74-76 week & 4 & $75.9 \pm 1.43$ & $72.9 \pm 2.04$ & $75.3 \pm 1.69$ & $72.8 \pm 0.44$ & NS \\
\hline 76-78 week & 4 & $74.4 \pm 2.40$ & $73.7 \pm 0.59$ & $72.4 \pm 2.80$ & $72.2 \pm 3.21$ & NS \\
\hline Total $(74-78)$ & 12 & $74.4 \pm 1.39$ & $72.9 \pm 0.71$ & $73.8 \pm 1.13$ & $72.8 \pm 0.35$ & NS \\
\hline \multicolumn{7}{|l|}{ Egg weight (g) } \\
\hline 72 week (begining of experiment) & 8 & $67.2 \pm 1.63$ & $64.6 \pm 1.90$ & $68.9 \pm 2.08$ & $65.5 \pm 2.10$ & NS \\
\hline 74 week & 8 & $67.5 \pm 2.13$ & $71.5 \pm 4.39$ & $65.2 \pm 3.78$ & $68.3 \pm 2.71$ & NS \\
\hline 76 week & 8 & $66.6 \pm 1.65$ & $70.7 \pm 3.15$ & $68.1 \pm 1.94$ & $68.7 \pm 1.38$ & NS \\
\hline 78 week & 8 & $68.5 \pm 1.66$ & $71.2 \pm 1.84$ & $65.3 \pm 2.43$ & $68.8 \pm 1.25$ & NS \\
\hline Total (74-78 week) & 24 & $67.5 \pm 1.01$ & $71.1 \pm 1.82$ & $66.2 \pm 1.58$ & $68.6 \pm 1.10$ & NS \\
\hline \multicolumn{7}{|l|}{ Marketable egg ratio (\%) } \\
\hline 72-74 week & 4 & $93.5 \pm 2.07$ & $92.1 \pm 2.54$ & $93.1 \pm 2.05$ & $96.1 \pm 0.37$ & NS \\
\hline 74-76 week & 4 & $93.6 \pm 2.25$ & $92.9 \pm 2.03$ & $97.3 \pm 0.77$ & $96.6 \pm 1.60$ & NS \\
\hline 76-78 week & 4 & $89.5^{\mathrm{b}} \pm 1.07$ & $92.6^{\mathrm{ab}} \pm 1.18$ & $96.5^{\mathrm{a}} \pm 1.32$ & $97.4^{\mathrm{a}} \pm 0.58$ & $* *$ \\
\hline Total (74-78 week) & 12 & $92.2^{\mathrm{b}} \pm 1.13$ & $92.5^{\mathrm{b}} \pm 1.05$ & $95.7^{\mathrm{ab}} \pm 0.94$ & $96.6^{\mathrm{a}} \pm 0.58$ & $* *$ \\
\hline
\end{tabular}

\footnotetext{
$\overline{\mathrm{a}, \mathrm{b}}$ Mean values within a row with different superscripts are significantly different. ${ }^{* *} \mathrm{p}<0.01$.
} $\mathrm{NS}=$ Not significant, results are expressed as means \pm standard errors. 
Table 4. The effect of CLP on eggshell quality (shell strength, thickness, ash, damaged egg ratio)

\begin{tabular}{|c|c|c|c|c|c|c|}
\hline \multirow{2}{*}{ Parameters } & \multicolumn{6}{|c|}{ Groups } \\
\hline & $\mathrm{N}$ & Low $\mathrm{Ca}(3.5 \%)$ & Optimum Ca (4.2\%) & $1 \%$ CLP & $2 \% \mathrm{CLP}$ & $\mathrm{P}$ \\
\hline \multicolumn{7}{|l|}{ Eggshell strength $(\mathrm{N})$} \\
\hline 72 week (start of experiment) & 8 & $26.2 \pm 0.86$ & $28.4 \pm 1.93$ & $28.8 \pm 2.35$ & $29.8 \pm 1.31$ & NS \\
\hline 74 week & 8 & $25.2 \pm 0.60$ & $27.1 \pm 2.93$ & $27.4 \pm 2.61$ & $29.3 \pm 1.12$ & NS \\
\hline 76 week & 8 & $25.5 \pm 0.34$ & $29.6 \pm 0.86$ & $27.1 \pm 2.82$ & $28.3 \pm 0.79$ & NS \\
\hline 78 week & 8 & $27.8 \pm 1.18$ & $28.4 \pm 1.29$ & $26.1 \pm 1.88$ & $30.6 \pm 0.26$ & NS \\
\hline Total (74-78 week) & 24 & $25.8 \pm 0.32^{\mathrm{b}}$ & $28.3 \pm 1.08^{\mathrm{ab}}$ & $26.9 \pm 1.37^{\mathrm{ab}}$ & $29.4 \pm 0.49^{\mathrm{a}}$ & $*$ \\
\hline \multicolumn{7}{|l|}{ Eggshell thickness $(\mathrm{mm} / 100)$} \\
\hline 72 week (start of experiment) & 8 & $33.7 \pm 0.91$ & $31.7 \pm 1.49$ & $31.3 \pm 0.80$ & $33.0 \pm 1.40$ & NS \\
\hline 74 week & 8 & $31.9 \pm 1.62$ & $34.1 \pm 0.45$ & $32.5 \pm 1.67$ & $32.0 \pm 1.59$ & NS \\
\hline 76 week & 8 & $35.2 \pm 1.03$ & $33.4 \pm 1.07$ & $31.9 \pm 1.09$ & $31.7 \pm 0.85$ & NS \\
\hline 78 week & 8 & $33.2 \pm 0.95$ & $35.0 \pm 1.08$ & $33.9 \pm 1.26$ & $33.8 \pm 1.30$ & NS \\
\hline Total (74-78 week) & 24 & $33.4 \pm 0.74$ & $34.2 \pm 0.52$ & $32.7 \pm 0.77$ & $32.5 \pm 0.73$ & NS \\
\hline \multicolumn{7}{|l|}{ Eggshell ash (\%) } \\
\hline 72 week (start of experiment) & 8 & $97.4 \pm 0.15$ & $97.1 \pm 0.14$ & $97.5 \pm 0.08$ & $97.5 \pm 0.09$ & NS \\
\hline 74 week & 8 & $97.5 \pm 0.12$ & $97.3 \pm 0.04$ & $97.5 \pm 0.14$ & $97.8 \pm 0.09$ & NS \\
\hline 76 week & 8 & $97.2 \pm 0.22$ & $97.2 \pm 0.13$ & $97.3 \pm 0.14$ & $97.7 \pm 0.12$ & NS \\
\hline 78 week & 8 & $97.3 \pm 0.09$ & $97.5 \pm 0.14$ & $97.2 \pm 0.25$ & $97.7 \pm 0.15$ & NS \\
\hline Total (74-78 week) & 24 & $97.3^{\mathrm{b}} \pm 0.08$ & $97.4^{\mathrm{b}} \pm 0.07$ & $97.3^{\mathrm{b}} \pm 0.11$ & $97.7^{\mathrm{a}} \pm 0.07$ & $* *$ \\
\hline \multicolumn{7}{|l|}{ Damaged egg ratio (\%) } \\
\hline 72-74 week & 4 & $6.5 \pm 2.07$ & $8.0 \pm 2.54$ & $6.9 \pm 2.04$ & $3.9 \pm 0.37$ & NS \\
\hline 74-76 week & 4 & $6.4 \pm 2.25$ & $7.1 \pm 2.03$ & $2.7 \pm 0.77$ & $3.4 \pm 1.60$ & NS \\
\hline 76-78 week & 4 & $10.5^{\mathrm{a}} \pm 1.06$ & $7.4^{\mathrm{ab}} \pm 1.18$ & $3.5^{\mathrm{b}} \pm 1.32$ & $2.6^{\mathrm{b}} \pm 0.58$ & $* *$ \\
\hline Total (74-78 week) & 12 & $7.8^{\mathrm{a}} \pm 1.13$ & $7.5^{\mathrm{a}} \pm 1.37$ & $4.3^{\mathrm{ab}} \pm 0.94$ & $3.4^{\mathrm{b}} \pm 0.58$ & $* *$ \\
\hline
\end{tabular}

${ }^{\mathrm{a}, \mathrm{b}}$ Mean values within a row with different superscripts are significantly different. ${ }^{*} \mathrm{p}<0.05, * * \mathrm{p}<0.01$.

$\mathrm{NS}=$ Not significant, results are expressed as means \pm standard errors.

were significantly decreased when compared with no CLP groups in pooled data (74-78) of $2 \%$ CLP. But there were no significant difference at data of $72-76$ weeks. The differences in marketable egg ratio were parallel with damaged egg ratio (Table 3). At the end of experiment, tibia characteristics (ash, calcium and phosphorus) were similar in all groups while the blood calcium level (Table 5) was significantly increased in $2 \%$ CLP group in comparison to the low $\mathrm{Ca}(3.5 \%)$ group $(\mathrm{p}<0.05)$. Furthermore, a marked increase of manure dry matter percentage (Table 5) was observed in both doses of the CLP, at the end of the experiment $(\mathrm{p}<0.01)$ in comparison to the CLP free groups. Any hen was died throughout the experiment.

\section{DISCUSSION}

Adding CLP to the diets of layers from 72 to 78 week of age did not cause any significant difference in terms of feed

Table 5. The effect of CLP on tibia ash, mineral concentrations, blood calcium and manure dry matter in laying hens

\begin{tabular}{lcccccc}
\hline \multirow{2}{*}{ Parameters } & \multicolumn{5}{c}{ Groups } \\
\cline { 2 - 7 } & $\mathrm{N}$ & Low Ca (3.5\%) & Optimum Ca (4.2\%) & $1 \%$ CLP & $2 \%$ CLP & P \\
\hline Tibia ash (\%) & 8 & $62.0 \pm 0.69$ & $62.5 \pm 0.56$ & $60.8 \pm 0.92$ & $61.6 \pm 1.33$ & NS \\
Tibia calcium (\%) & 8 & $22.8 \pm 0.97$ & $21.6 \pm 0.89$ & $21.4 \pm 1.16$ & $21.7 \pm 0.90$ & NS \\
Tibia phosphor (\%) & 8 & $11.4 \pm 0.50$ & $10.7 \pm 0.03$ & $10.4 \pm 0.24$ & $10.7 \pm 0.27$ & NS \\
Blood calcium (mmol/L) & 8 & $3.50^{\mathrm{b}} \pm 0.15$ & $3.78^{\mathrm{ab}} \pm 0.09$ & $3.57^{\mathrm{ab}} \pm 0.04$ & $3.94^{\mathrm{a}} \pm 0.08$ & $*$ \\
Manure dry matter (\%) & & & & $23.7 \pm 1.53$ & $23.9 \pm 0.33$ & $\mathrm{NS}$ \\
$\quad$ At the beginning & 4 & $22.4 \pm 1.19$ & $23.5 \pm 1.42$ & $23.4^{\mathrm{a}} \pm 0.85$ & 2.38 & $* *$ \\
At the end & 4 & $21.0^{\mathrm{b}} \pm 0.85$ & $21.0^{\mathrm{b}} \pm 0.38$ & 238 & \\
\hline
\end{tabular}

$\overline{\mathrm{a}, \mathrm{b}}$ Mean values within a row with different superscripts are significantly different. ${ }^{*} \mathrm{p}<0.05,{ }^{* *} \mathrm{p}<0.01$. $\mathrm{NS}=$ Not significant, results are expressed as means \pm standard errors 
consumption, FCR or egg production. Similarly, the lack of response exhibited by feed consumption and FCR with CLP supplementation concurs with previous reports by Olver (1989), Roland (1988) and Öztürk et al. (1998), but it doesn't concur with some reports which are about effect of SZ on feed consumption (Miles et al., 1986) and FCR (Roland and Dorr, 1989). There were no significant differences in egg weight (Table 3). Also, CLP had no effect on egg weight in a similar study (Elliot and Edwards, 1991). On the contrary, Mostaghian et al. (1991) demonstrated a reduction of the egg weight when the dietary SZ content was $1 \%$. In the present experiment, the lack of response on egg weight, feed consumption and FCR by CLP supplementation may be explained by the hypothesis that CLP and SZ, which has different ion exchange capacity, may exhibit different effects in digestive system (Elliot and Edwards, 1991).

Egg shell thickness was not affected by CLP addition. This confirms the earlier findings of Öztürk et al. (1998) and Yalçın et al. (1987). Whereas, feeding hens with $0.5 \%$ CLP enhanced shell thickness (Olver, 1989). Eggshell strength and ash were not affected by CLP addition when these parameters were individually analyzed in measurement periods $\left(74^{\text {th }}, 76^{\text {th }}\right.$ and $78^{\text {th }}$ weeks $)$. However; eggshell strength and ash were shown a significant increase by $2 \%$ CLP supplementation when pooled data were analyzed. CLP supplementation did not affect damaged egg ratio both in $74^{\text {th }}$ and $76^{\text {th }}$ weeks. But, $2 \%$ CLP addition decreased damaged egg ratio between $76^{\text {th }}-78^{\text {th }}$ weeks and pooled data $\left(74^{\text {th }}-78^{\text {th }}\right.$ weeks). Also, marketable egg ratio was improved by $2 \%$ CLP addition just like damaged egg ratio. Clinoptilolite addition to diets tents to affect eggshell quality after 6 weeks. These data show that positive effects of CLP are even more obvious after prolonged exposure to Ca-deficient diets. Feeding laying hens with both CLP and SZ improve eggshell quality has been reported (Roland et al., 1985; Olver, 1989; Keshavarz and McCormick, 1991). Roland et al. (1985) hypothesized that the beneficial effect of CLP on eggshell quality is related to its high affinity to $\mathrm{Ca}$ and its high ion-exchange capability. Additionally, it is suggested that improvement of eggshell quality may associated with increased serum $\mathrm{Si}$ concentration which originated from CLP (Carlisle, 1981; Ballard and Edwards, 1988). The primary effect of $\mathrm{Si}$ in bone and cartilage is thought to be at matrix synthesis which has significant influence on calcification (Carlisle, 1984; Carlisle, 1986).

The information from the authors' laboratory (Austic, 1984; Austic and Keshavarz, 1988) and in conjunction with other reports (Mongin, 1978; Hamilton and Thompson, 1980; Junqueira et al., 1984), has indicated that dietary electrolyte balance $(\mathrm{Na}+\mathrm{K}-\mathrm{Cl})$ has a significant impact on body fluid acid-base balance and eggshell quality. It has been reported that zeolite supplementation decreased the serum $\mathrm{Cl}$ levels (Roland et al., 1990). Besides, sodiumcontaining compounds have also been considered to influence acid-base balance in the physiology of eggshell formation (Mongin, 1968). Therefore, it is plausible that the beneficial effect of CLP on eggshell quality, at least in part, may be attributed to its effect on acid-base balance.

Dietary CLP failed to influence tibia ash, $\mathrm{Ca}$ and $\mathrm{P}$ ( $p>0.05$ ), in contrast to other studies (Carlisle, 1986; Watkins and Southern, 1991). Plasma calcium was increased with 2\% CLP supplementation when compared to low $\mathrm{Ca}(3.5 \%)$ group. Data of plasma $\mathrm{Ca}$ levels are in agreement with Leach and Burdette (1990). However, some authors reported that CLP did not influence serum Ca level (Miles et al., 1986; Elliot and Edwards, 1991).

The manure dry matter of the hens fed with diets containing CLP were higher than those of hens fed without CLP $(p<0.01)$. This may be due to the high water-absorbing capacity of CLP (Olver, 1989; Palmer et al., 1992).

The expected effects of zeolites on animal experiments may exhibit variation due to such factors as the source, concentration, particle size, aluminium and silicon content of the zeolite, the level of $\mathrm{Ca}$ and $\mathrm{P}$ in the diet (Mumpton, 1984) and duration of experiment. Therefore, these factors may affect the experimental results.

In conclusion, decreased faecal moisture contents of hens by $2 \%$ CLP feeding can cause, less ammonia and fewer fly problems, lower risk for respiratoric diseases. However addition of CLP is more expensive than addition of $\mathrm{Ca}$, CLP can be more economic in long term feeding when considered from more marketable eggs and health of hens' point of view.

\section{ACKNOWLEDGMENTS}

The author wishes to express her appreciation to Enli Mining Company Limited, Manisa, Turkey, for kindly donating the CLP powder.

\section{REFERENCES}

AOAC. 1955. Fat-free basis. Method number 22.10, Official Methods of Analysis. $8^{\text {th }}$ ed., Washington, DC.

AOAC. 1984. Official methods of analysis of the association of official analytical chemist. $14^{\text {th }}$ ed., Arlington, Virginia.

Anonymous. 2007. Zeolites structure and types. web: http:// www.lenntech.com/zeolites-structure-types.htm

Austic, R. E. 1984. Excess dietary chloride depresses eggshell quality. Poult. Sci. 63:1773-1777.

Austic, R. E. and K. Keshavarz. 1988. Interaction of dietary calcium and chloride and the influence of monovalent minerals on eggshell quality. Poult. Sci. 67:750-759.

Ballard, R. and H. M. Edwards. 1988. Effects of dietary zeolite and vitamin A on tibial dyschondroplasia in chickens. Poult. Sci. 67:113-119. 
Balnave, D. and S. K. Muheereza. 1997. Improving eggshell quality at high temperatures with dietary sodium bicarbonate. Poult. Sci. 76:588-593.

Carlisle, E. M. 1981. Silicon in bone formation. In: Silicon and siliceous structures in biological systems (Ed. T. L. Simpson and B. E. Volcani). Springer Press, New York. pp. 69-94.

Carlisle, E. M. 1984. Silicon. In: Biochemistry of the essential ultra trace elements (Ed. E. Frieden). Plenum Press, New York. pp. 257-291.

Carlisle, E. M. 1986. Silicon as an essential trace element in animal nutrition. In: Silicon biochemistry (Ed. D. Evered and M. O'connor). Ciba Foundation Symposium 121, Chichester, John Wiley and Sons. pp. 123-139.

Elliot, M. A. and H. M. Edwards. 1991. Comparison on the effects of synthetic and natural zeolite on laying hen and broiler chicken performance. Poult. Sci. 70:2115-2130.

Hamilton, R. M. G. and B. K. Thompson. 1980. Effects of sodium plus potassium to chloride ratio in practical-type diets on blood gas levels in three strains of white leghorn hens and the relationship between acid-base balance and eggshell strength. Poult. Sci. 59:1294-1303.

Hartel, H. 1977. Between N-Corrected metabolisable energy and nutrient content of feeds for chickens. Arch. Geflugelk. 41:152-182.

Junqueira, O. M., R. D. Miles and R. H. Harms. 1984. Interrelationship between phosphorus, sodium and chloride in the diet of laying hens. Poult. Sci. 63:1229-1236.

Keshavarz, K. and C. C. McCormick. 1991. Effect of sodium aluminosilicate, oystershell and their combination on acid-base balance and eggshell quality. Poult. Sci. 70:313-325.

Leach, R. M. and J. H. Burdette. 1990. Broiler chicks fed lowcalcium diets. 1. Influence of zeolite on growth rate and parameters of bone metabolism. Poult. Sci. 69:1539-1543.

Miles, R. D., R. H. Harms and S. M. Laurent. 1986. Influence of SZA $\left(\right.$ Ethacal ${ }^{\circledR}$ ) on laying hen performance. Nutr. Rep. Int. 34:1097-1103.

Mongin, P. 1968. Role of acid-base balance in the physiology of egg shell formation. Worlds Poult. Sci. J. 24:200-230.

Mongin, P. 1978. Acid-base balance during egg shell formation. In: Respiratory function in birds, adult and embryonic (Ed. F. Piiper). Springer Press, New York. pp. 247-259.

Moshtaghian, J., C. M. Parsons, R. W. Leeper, P. C. Harrison and K. W. Koelkebeck. 1991. Effect of sodium aluminosilicate on phosphorus utilization by chicks and laying hens. Poult. Sci. 70:955-962.

Mumpton, F. A. and P. H. Fishman. 1977. The application of natural zeolites in animal science and aquaculture. J. Anim. Sci. 45(5):1188-1203.

Mumpton, F. A. 1984. Use of natural zeolites in agriculture and aquaculture. In: Zeo-agriculture (Ed. W. G. Pond and F. A. Mumpton). Westview Press, Boulder, Colorado. pp. 33-34.
Olver, M. D. 1989. Effect of feeding Clinoptilolite (zeolite) to three strains of laying hens. Br. Poult. Sci. 30:115-121.

Öztürk, E., G. Erener and M. Sarıca. 1998. Influence of natural zeolite on performance of laying hens and egg quality. Turkish Journal of Agriculture and Forestry 22:623-628.

Palmer, L. A., T. K. Hagedorn, D. R., Ingran, R. A. Phillips, R. J. Firmin and M. D. Klemperer. 1992. Effects of selected substances on water consumption and resulting faecal moisture of white leghorn hens. Poult. Sci. 71(Supp. 1):385(Abstr.).

Patterson, P. H., K. W. Koelkebeck, D. D. Bell, J. B. Carey, K. E. Anderson and M. J. Darre. 2001. Egg marketing in national supermarkets: specialty eggs-part 1. Poult. Sci. 80(4):390-395.

Roland, D. A. 1980. The ability of young and old hens to change shell deposition with sudden neutral drastic changes in egg size. Poult. Sci. 59:924-926.

Roland, D. A., S. M. Sr. Laurent and H. D. Orloff. 1985. Shell quality as influenced by zeolite with high ion-exchange capability. Poult. Sci. 64:1177-1187.

Roland, D. A. 1988. Further studies of effects of phosphorus and aluminosilicates on egg shell quality. Poult. Sci. 67:577-584.

Roland, D. A. and P. E. Sr. Dorr. 1989. Beneficial effect of synthetic sodium aluminosilicate on feed efficiency and performance of commercial leghorns. Poult. Sci. 68:1241-1245.

Roland, D. A., H. W. Sr. Rabon, T. J. Frost, S. M. Laurent and D. G. Barnes. 1990. Response of commercial Leghorns to sodium aluminosilicate when fed different levels and sources of available phosphorus. Poult. Sci. 69(12):2157-2164.

Seaborn, C. D. and F. H. Nielsen. 1994a. Dietary silicon affects acid and alkaline phosphatase and ${ }^{45} \mathrm{Ca}$ uptake in bone of rats. The J. Trace Elem. Exp. Med. 7:1-11.

Seaborn, C. D. and F. H. Nielsen. 1994b. Effect of germanium and silicon on bone mineralisation. Biol. Trace Elem. Res. 42:151164.

Seaborn, C. D. and F. H. Nielsen. 2002a. Silicon deprivation decreases collagen formation in wounds and bone, and ornithine transaminase enzyme activity in liver. Biol. Trace Elem. Res. 89:251-261.

Seaborn, C. D. and F. H. Nielsen. 2002b. Dietary silicon and arginine affect mineral element composition of rat femur and vertebra. Biol. Trace Elem. Res. 89:239-250.

Street, C. 1994. Natural zeolites in animal feeds. Feed Compounder, Februrary.

Tukey, J. W. 1949. Comparing individual means in the analysis of variance. Biometrics 36:99-114.

Watkins, K. L. and L. L. Southern. 1991. Effect of dietary sodium zeolite A and graded levels of calcium on growth, plasma, and tibia characteristics of chicks. Poult. Sci. 70:2295-2303.

Yalçın, S., A. Ergun, I. Çolpan and K. Küçükersan. 1987. Zeolitin yumurta tavukları üzerindeki etkileri. Lalahan Hayvancıllk Araştırma Enstitüsü Dergisi 27(1-4):28-49. 